\title{
TEACHER COASSESSMENT PROCESS IN HIGHER EDUCATION
}

\author{
PROCESO DE COEVALUACIÓN DOCENTE \\ EN EDUCACIÓN SUPERIOR
}

\author{
MÓNICA TORRES-CAJAS ${ }^{\star}$, ADRIANA LARA-VELARDE $^{\star *}$, \\ DANILO YÉPEZ-OVIEDO*** EDGAR HEREDIA-ARBOLEDA****
}

Aвstract: The students' learning results are closely related to the quality of teachers. Consequently, teaching practice implies a continuous search of the results it produces. The quality education policies in higher education institutions should be directed to transform the culture of performance evaluation into peer evaluation; trying to overcome the resistance it generates in many educational environments, especially those that are not linked to this culture. This bibliographic research aims to develop a discussion about a process of co-evaluation to favor the improvement of the teacher and the educational institution, through a practical four-stage process: Pre Observation, Observation, Post Observation and Critical Refection that encourages new ways to facilitate knowledge.

Keywords: Co-evaluation, Peer Evaluation, Teacher evaluation, Evaluation Stages.

RESUMEN: Los resultados de aprendizaje de los alumnos están estrechamente relacionados con la calidad de los docentes. En consecuencia, la práctica docente implica una búsqueda continua de los resultados que produce. La política de calidad en instituciones de educación superior debería estar dirigida a transformar la cultura de la evaluación del desempeño docente, hacia una evaluación por pares; tratando de superar la resistencia que genera en muchos entornos educativos, especialmente aquellos que no están vinculados a esta cultura. Esta investigación bibliográfica tiene como objetivo

* Ph.D en Educación. Académica de la Universidad Nacional de Chimborazo, Facultad de Ciencias de la Educación Humanas y Tecnologías, Riobamba, Ecuador: Correo electrónico: mtorres@unach.edu. ec. Orcid: https://orcid.org/0000-0002-2099-7245

** Magister en Enseñanza del Idioma Inglés como Lengua Extranjera. Académica de la Universidad Nacional de Chimborazo, Facultad de Ciencias de la Educación Humanas y Tecnologías, Riobamba, Ecuador. Correo electrónico: alara@unach.edu.ec. Orcid: https://orcid.org/0000-0002-2270-6843

*** Magister en Gestión de la Educación. Académico de la Universidad Nacional de Chimborazo, Unidad de Competencias Lingüísticas, Riobamba, Ecuador. Correo electrónico: dyepez@unach.edu.ec. Orcid: https://orcid.org/0000-0003-0265-7797

${ }_{* * * *}$ Magister en Enseñanza del Idioma Inglés como Lengua Extranjera. Académico de la Universidad Nacional de Chimborazo, Facultad de Ciencias de la Educación Humanas y Tecnologías, Riobamba, Ecuador Correo electrónico: eheredia@unach.edu.ec. Orcid: https://orcid.org/0000-0002-4099-9811 
desarrollar una discusión sobre un proceso de co-evaluación para favorecer la mejora del profesor y la institución educativa. A través de un proceso práctico de cuatro etapas: Pre Observación, Observación, Post Observación y Refexión Crítica que aliente nuevas formas de facilitar el conocimiento.

Palabras clave: Co-evaluación, evaluación de pares, evaluación docente, etapas de co-evaluación.

Recibido: 31.03.2020. Aceptado: 01.05.2021.

\section{INTRODUCTION}

D esembling societr, educational processes are constantly changing; their dynamic and flexible nature requires professionals who are capable of assessing their environment, their own pedagogical practice, solving problems, making decisions that enhance the development and the quality of human beings (Díaz et al., 2015).

Much has been said about teacher evaluation in recent times, especially considering the intention of the Ecuadorian government to improve the quality of education at all levels. Although it is a necessity, it has been rejected by the educational stakeholders since on many occasions it has been misinterpreted or misapplied (Kohut, Burnap \& Yon, 2007).

The modality of peer evaluation as part of the integral teaching evaluation, defined in the Career and Category Regulations of the University Professor and Researcher (2012), constitutes a mechanism for the development of a shared and co-responsible evaluation. As noted by Valero and Blasco (2013), in a co-evaluation, each teacher will have an evaluating pair with whom they will develop a critical and constructive reflection of their actions.

However, in many higher education institutions, at the national level, teachers' evaluation is originally driven to fulfill a part of the requirements for institutional accreditation, and no importance is given to the potential scope of the Teacher Performance Evaluation as a mean of collective and continuous improvement based on the work of the entire teaching faculty so that this evaluation is oriented towards learning, dialogue, and joint reflection.

The evaluation of teachers' performance, although it generates resistance in many educational environments, especially in those that are not part of a culture of evaluation, should be seen as a strategy to favor the improvement of the teachers as well as the institutions.

Although it is known that teachers' assessment is necessary, there are 
no clear guidelines on how to put it into practice so that it becomes a true transformation process of the educational practice which would encourage new ways to facilitate knowledge and prepares students to face the complex global challenges.

In this regard and with a view to developing a process of teaching coevaluation with the formation of academic peers who, can truly reflect on the educational act this article is developed based on the bibliographic analysis of important information from numerous sources. Various approaches, basic points that should be covered and that deserve to be considered to carry out in this process, have been found. Therefore, it is important to grant teachers spaces where they can actively organize, promote, and participate in the Assessment of teacher's performance.

\section{BACKGROUND}

Considering the role of the university as an architect for social change, higher education teachers require an accurate knowledge of the effectiveness of the teaching practice that allows supporting the academic and institutional performance. Patricia Ávila (2009) argues that peer observation in teaching is a tool that provides rich and qualitative evidence for teachers, which allows them to encourage meaningful learning and to confront the difficulties that can be evidenced in the teaching-learning process (Mohammed, 2017).

The teaching work goes beyond its performance in the classroom, such as management, research, and linking, which also affect learning in some way. It focuses on the leading role of the teachers in improving the quality of education that is evident in several areas of their work in the classroom, such as methodology, resources, curriculum planning, evaluation, classroom management, and their attitude towards education.

Wingrove, Hammersley-Fletcher, Clarke y Chester (2017) in their scientific article "Leading the development of peer observation of higher education: Australia and England perspectives, point out that peer observation is a challenge to implement and grow which must be supported by the fundamental values of respect, academic scholarship, freedom, and integrity. It is also supported that, in addition to experience in learning and teaching and the provision of resources, it is also vital to establish a supportive and constructive academic environment; to provide experiences that affirm educational excellence; to develop a culture that values the erudition of teach- 
ing; to promote self-assessment, reflection, and personal growth; and to improve teaching and learning based on constructive support.

Josh Tenenberg (2016) in his article "Learning through observing peers in practice," concludes that teachers, when observing each other, focus on professional vision, on the adapted way of seeing the field of practice to make the observed scene intelligible. In doing so, they focus on a "double vision" of their own classroom compared to the classroom they observe. This activity forces the teacher to assign objects, relationships, and actions regarding the class that is observed. At the same time, it addresses the differences between these two environments, in terms of student behavior and teacher actions that precede this behavior.

Consequently, the observer constructs a problem and a solution by a comparative logic that relates causes to effects. In this activity, both observer and observed emerge together from the activity. Finally, when implementing a change in our own practice to solve the identified problem, the pragmatic restrictions of your environment force us to reconsider and treat all the details that distinguish our own classroom from those of our colleagues who were put aside to see these scenes as approximately equivalent. The structural conditions are established to benefit both the observer and the observed.

L. Gonzalez and R. Gonzalez (2014) conducted a study using peer evaluation processes among professors and students in a Mexican university, with the participation of 43 teachers and 93 students from 10 bachelor's degrees, who after this experience recognized the formative advantages of this type of evaluation.

\section{TEACHERS EVALUATION}

Currently, teacher evaluation has become a significant component in the teaching-learning process due to the fact that students' performance will depend on the quality of teachers. Today, evaluation is a topic of great debate since this process is carried out superficially without considering that it plays a very important role in education.

As a result, evaluation is considered as an orderly, sequential and systematic process that aims to obtain information either qualitatively or quantitatively through the application of various techniques and instruments according to previously stablished parameters with the objective of using the gathered results for decision making in order to improve the edu- 
cational process. In this context, Dimaté, Tapiero, González, Rodríguez y Arcila (2017) mention that evaluation is a process aimed at decision-making, which is carried out prior to the establishment of assessment criteria in order to contribute to the development of education.

As previously stated, the evaluation process involves critical and complex aspects as it is executed based on a reflexive analysis of the teaching practice and the teacher's performance in the classroom. This process must be formative so that it seeks to identify the strengths and weaknesses of the teaching work by considering the search for the improvement of the educational process as a fundamental aspect, consequently the need to improve professionally arises. Teaching evaluation must be carried out in an authentic, critical, comprehensive manner (UNESCO 2014). In this sense, it is necessary to emphasize that every educational process intends to contribute significantly to society as it is considered as the starting point that allows achieving quality in the teaching practice in order to increase its effectiveness (Ronquillo, Moreira \& Verdesoto, 2016).

The evaluation of the teaching practice at any educational level requires collecting information about what is being done within the classroom to subsequently look for alternatives that allow overcoming the difficulties that may be encountered. Consequently, the following questions arise, why is it necessary to evaluate the teaching practice?, and what should be evaluated? There have been several answers to these questions. However, the majority agrees that when evaluating, there must be suggestions to improve the teaching practice by analyzing the evaluation criteria, making a thorough study of each of these parameters to make decisions that allow changing the educational model finally. Regarding the question: What should it be evaluated? Basically, professional competencies are considered, so that the decision-making process leads teachers improve their professional competences.

According to Contreras (2018), the teaching competencies are defined as the set of resources - knowledge, skills, and attitudes that teachers need to satisfactorily resolve the situations they face in their professional work, which can be academic: methodological processes, strategies, techniques, resources, classroom management, organization and selection of content, and the ways of evaluating that will be previously analyzed to see if they contribute or not to students achieve a significant learning. Teachers will also have to deal with personal situations: initiative, responsibility, risk-taking, and creativity. And situations of a social nature: teamwork, networking, empathy, compassion. All these aspects will have a direct influence on 
the development of the specific competencies and skills required by those who learn in order to be prepared for life, work, and successfully face the challenges of the 21st century (Muñoz, Villagra \& Sepúlveda, 2016).

\section{TEACHING COEVALUATION - WHAT IS ACADEMIC PEER OBSERVATION?}

Teaching co-evaluation or also known as peer evaluation, or shared evaluation is another dimension of the evaluation process in education. It is a critical process that allows teachers to evaluate their practice and teaching performance with the purpose of reflectively analyzing how teaching-learning is being developed. This process allows authorities, administrators, teachers, and students to know their own strengths and weaknesses, suggest corrective actions, and apply them in order to propose improvement options.

For Grainger, Crimmins y Burton (2016) teaching co-evaluation is a mode of evaluation in which two or more subjects are part of a process in the academic field, which provides information about teaching work through a systematic procedure in which professional observation and education are involved. The use of techniques and instruments with formative criteria that will allow providing meaningful opinions in order to improve the teaching process.

Similarly, Vizcaíno, Marín y Ruiz (2017) affirm that co-evaluation becomes a training experience that, during its development, helps both the observer and the observed teacher to be actively involved in this process and, at the same time, to contribute to their formation both professionally and personally.

O'Leary y Price (2016) define peer observation as a collaborative model where peers come together to observe each other's practice. Furthermore, they point out that this meeting is not an end in itself, but the scenario where ideas can be expressed and a reflective dialogue is stimulated.

In everyday life, it is still believed that the intervention of external evaluation agents threatens university autonomy and much more with the academic freedom. (Martínez, Tobón \& Romero, 2017; Toscanini, Aguilar \& García, 2016). It is precisely these perceptions that do not allow university education systems to adapt to the social dynamism required by the globalization of knowledge (Keig, 2000). Changing this type of perceptions is undoubtedly one of the biggest challenges that Ecuadorian education face at all levels since modifying anachronistic cultural-educational aspects of 
the micro-curriculum with an innovative and adjusted to the needs of the higher education institutions is threatening for a large teaching population (Magaña Figueroa \& Flores Hernández, 2015; Fletcher, 2018).

The peer evaluation process to improve the micro-curriculum is not snobbery. In fact, a study carried out in Iran indicates the importance of visualizing peer observation as a tool for continuous professional development with the help of public educational policies (Motallebzadeh, Hosseinnia \& Domskey, 2017).

Similarly, regarding the advantages of peer evaluation, researchers in Asia, the United Kingdom, and the United States have affirmed that this method of evaluation-observation among teachers improves the learning process in students (Dos Santos, 2017; Jones \& Gallen, 2016; Santos \& Miguel, 2016, Tenenberg, 2016).

\section{ACADEMIC PEER}

The academic peer plays a fundamental role in the process of teaching Coevaluation because it is the one who performs the analysis and reflection of the pedagogical practice by observing and collecting data through different sources (Grainger, Bridgstock \& Houston, 2015). Additionally, the academic peer is considered as an equal, as a subject with whom one has things in common, and, in the educational context, they are known as someone who is immersed in the same area of education or the same discipline in teaching. Therefore, the academic peers are in charge of issuing their criteria in relation to the co-evaluation process that was previously developed; that is to say, he or she provides information on how the teaching practice is taking place whether the objectives set are met or not, if planning is elaborated according to the curriculum or if there is an appropriate learning environment for students and other criteria that are relevant in the peer assessment.

During the co-evaluation process, the academic peer contributes to the improvement of the evaluated peer since it constitutes a powerful tool that provides information and gives individual feedback on teaching practice (Fletcher, 2018). According to Contreras (2018) the evaluating peers are professionals who belong to the same academic line who are responsible for conducting an observation process that involves two teachers and in which the evaluating couple focuses on analyzing the educational practice to later offer constructive feedback to his coworkers in the academic field. This process entails several advantages because once the observation is 
made the academic pair makes a reflection on the methods, the techniques that were applied, and the teaching strategies. Therefore, both the observed and the observer benefit from each other since when reviewing the descriptive data collected during the on-site visit, suggestions to improve learning outcomes are presented, and solutions and strategies can then be proposed, which will allow enhancing their teaching practice. In addition, this process involves collaboration and interaction among colleagues. That is why the academic peer fulfills a primary function in the evaluation because, when interaction occurs between them, a collaborative environment is created that has as a common goal the quality in education.

As claimed by Gonzalez (2014), academic peers generally must be teachers who have in common the same area of knowledge, or are related in specialties. This way it becomes a cooperative entity that will allow offering new alternatives for improving the teaching practice because then improvement strategies can be exchanged based on the results obtained from the co-evaluation process.

\section{CHARACTERISTICS OF AN ACADEMIC PEER}

The co-evaluation process involves two related teachers in knowledge areas being immersed in the process of observing their teaching practice. In this regard, it is essential that the evaluating academic peer has certain characteristics that will allow this process to be carried out in a more objectively and truthfully. Therefore, the first parameter to consider in peer evaluation is that the evaluating teacher should have knowledge about the principles, methodologies, processes, strategies that are carried out in his area, which would allow an integral examination of the teaching-learning process of the evaluated teacher. In addition, academic peers must be able to understand and evaluate the teacher's role in the classroom, leaving aside the subjectivity that may occur during this process. Moreover, it is recommended that every academic pair analyzes in-depth their teaching practice; that is to say to be capable of highlighting the relevant results during the co-evaluation and in the same way the teacher must report the issues that were not carried out effectively without passing value that do not present concrete and specific conclusions.

Undoubtedly, it is essential that one of the characteristics that every academic pair must have is the knowledge of their area. However, there are other aspects that are also necessary, such as personal characteristics. That 
is why it is essential that the academic evaluator must have a high degree of honesty when evaluating in order to present objective results. Another important personal quality that every academic pair must have is truthfulness, sincerity, and also, he must master the appropriate language. In addition, the academic pair must have a high level of discretion about the results obtained during the observation, due to the fact these must be handled under strict reserve without allowing their value judgment to be manipulated or modified.

In the professional field, the academic peer must have academic suitability since he or she must assume a critical constructivist position towards the observed pair. It will allow the conclusions drawn from this process to contribute to the improvement of education. His evaluation should be based on the guidelines established for this process in order to identify the possible elements that should be modified or improved in the teaching exercise.

Finally, it is important that the academic peer should also have certain ethical principles under which they will act during the evaluation process; for instance: he or she must be loyal to Universidad Nacional de Chimborazo and its institutional values. They must comply with the regulations established in the evaluation process. Besides, they must keep the results of the co-evaluation process confidentiality and act during this process with impartiality, integrity, and promptness.

\section{STAGES OF OBSERVATION IN ACADEMIC PEERS}

\section{Pre-observation}

Teaching co-evaluation is a mode of evaluation in which two or more academics are part of a process that provides information about teaching work based on a systematic procedure involving professional observation and the use of techniques and instruments with training criteria that will allow providing meaningful opinions in order to improve it (Grainger et al., 2016). In this context, this process involves stages that allow the academic peer to demonstrate how the teaching practice is being executed through a systematic and organized process of observation.

The first stage in the co-evaluation of academic peers is the Pre - observation, which involves a meeting that takes place between the two academic peers, the observer teacher and the one observed in order to diagnose 
teaching practices, and at the same time identify strengths and weaknesses (Muñoz, Villagra \& Sepúlveda, 2016). The objective of this stage is to have a dialogue between both parties about what is intended to be developed in the class; The observed teacher must present his planning (Contreras, 2018). In addition, the observer teacher must be informed about particularities considered in class planning, what are the contents, objectives, learning outcomes, etc. This process will allow us to have a broader vision of what students will be able to do at the end of the class, whether or not the class is related to semiannual planning, or whether or not a class is planned in advance.

Additionally, at the meeting, it is recommended that the observer teacher reviews what teaching resources will be used during the classes, these may be: syllabus, planning, didactic material, tests, assigned tasks, or any other teaching resource that the teacher to be observed has previously prepared for the teaching. All these with the purpose of knowing what the observed teacher will do and if the materials included in the lesson plan are used.

Another aspect to be considered at this stage is to decide how the class observation will be evidenced, that is to say, if it will be recorded, documented by taking notes or using a rubric (Fletcher, 2018).

In addition, this process will also allow the observed teacher to suggest that the observer teacher should pay attention to certain aspects in which he/ she would like to receive feedback on (Center for Teaching Support \& Innovation, 2017). In the same way, this process offers benefits for the observer teacher because as stated by Richard (2019) the observers through the observation have the opportunity to make a self-reflection of their teaching practice and make significant changes that allow them to improve the execution of their classes.

It is necessary that the observer teacher knows what his functions will be in this process; in other words, what he will do at this stage. The observation sheet or the instrument that will be used for the observation must be reviewed in detail, the date, the place must be set, and the resources that will be required for the pre-observation meeting must be detailed in advance. Likewise, the observed teacher must know that in this process, his role is to provide the observer teacher with the necessary information required. In addition, the observed teacher should understand that this process is not a stage in which he/she will be judged about his/her teaching practice, instead, this process will become a basis in order to reflect about the teachinglearning process and then to suggest improvement actions (Eri, 2014). 


\section{Observation}

Obviously, the process of peer observation involves a certain level of complexity, and especially in the process of observation due to the fact that the lack of culture in this area makes the observed teacher perceive it as a form of invasion to academic freedom or to his/ privacy.

At this stage, the observer makes an on-site visit in order to know and demonstrate how the teaching practice is being developed through the use of techniques and instruments that allow the evaluation of the pedagogical aspects of the teaching practice. In an academic peer review, a basic set of criteria in the observation process are to be used, this will be established according to the needs detected daily; these criteria must fit the educational model of the institution and contribute to better student's learning.

Some of these criteria have already been implemented in foreign universities such as Ryerson University, Canada; Macquarie University, Australia; Queensland University, Australia, Victoria University of Wellington. Therefore, the ones that are considered of vital importance are: the objective of the class, its organization and structure, the approach, selection and use of materials and activities, rhythm and scope of the class, the atmosphere that is established in terms of diversity and inclusion, methods and techniques employed, classroom management, feedback, development of critical thinking skills, and forms of learning assessment.

According to Ávila (2009), the observation is intended to collect the necessary information that will provide feedback to the observed teacher. These documents will then be useful for the academic pair to carry out a critical analysis of the process and how it will influence the learning of his / her students (Contreras, 2018).

During the visit, the observer teacher him /herself must take should introduce the observer peer to the class and indicate the reason why he/ she is there. The observer will be located in a place where he / she does not obstruct the vision, nor attract the attention of the students. The observer will take note of the pertinent aspects using the proposed formats and should not interrupt or intervene in the class (Âvila, 2009). It is necessary to point out that the observer must have a simple and friendly attitude since it will allow the observed teacher and the students to feel comfortable, and relaxed. This will enable them to show their normal level of achievement. The observation process is intended for both observer and observed to recognize strengths and suggest possible areas of attention or alternative approaches to professionally benefit from this experience, rather than just judge (Martin \& Double, 1998). 
A series of formats and checklists have been prepared by researchers or people in charge of teacher evaluation departments in Higher Education institutions. This research suggests a scheme for our institution, which we consider pertinent to help teachers accept peer observation as a means of learning through the reflection on the other's performance. Therefore, this will be considered as a natural means of professional and personal growth without feeling threatened, nervous, or suspicious of what the observation is.

Examples of the formats that have been developed based on this bibliographic review and according to our context can be reviewed in the appendices.

\section{Post-observation}

It is the meeting that takes place after the observation with the general purpose of providing feedback to the observed teacher through the perceptions of the observer peer which must be held in a positive climate to become a constructive dialogue for both (Alabi and Weare, 2014; Brix, Grainger \& Hill, 2014). The observer peer must describe what he/she observed, pointing out what he/she considers as positive aspects and those that need to be improved. It is recommended that the observed teacher give his/her opinion about this issue. It is important that at this stage not to impose points of view; instead, it is advisable to listen effectively and to ask questions to prompt the teacher's reflection (Fletcher, 2018). Subsequently, teachers and their peers together identify areas in which it may be useful to focus on implementing a development and improvement strategy in the future (Donnelly, 2007). The quality of the feedback depends on the amount of information that is granted. Therefore, it is possible that the observed teacher needs his or her peer to be more specific or precise about some particular issues in which he/she is interested.

In short, it is true to say that when the observer is providing feedback, some basic aspects should be considered, such as: Focus the feedback on the behavior rather than on the person, focus the feedback on observations rather than deductions, be specific in providing this feedback and all of the time share ideas and information instead of giving advice.

It is also important to consider that the feedback session is finite, just a few minutes, so it is important to focus on specific aspects and give priority to the main points of the observation (Wanjryb, 1992)

The creation of a non-threatening environment determines success in 
the feedback session where the observer teacher and observed teacher feel relaxed and confident so that teachers summarize what they think, encourage reflection, and clearly know what to improve in the future.

\section{Critical reflection}

Critical reflection is the last stage of the peer-observation process. It consists of reviewing and socializing with the teaching staff the stages of preobservation, observation, and post-observation with the purpose of invigorating academic praxis (Diaz-Maggioli, 2004). At this stage of critical reflection is where reflective feedback takes place in a symbiotic way; in other words, the host and his colleague-observer benefit from each other in academic terms, learning from each other all times (Magaña Figueroa \& Flores Hernández, 2015; Fletcher, 2018).

It should be noted that the reflexive process has to be carefully carried out since the disrespect of it would trigger the teachers' frustration. (McDaniel et al., 2019; Reyes-Chua, Remollo-Mack \& Viloria, 2019). Therefore, it is not about judging the host, but rather highlighting the most transcendental points of his/her class and possible aspects for teaching improvements (Yiend, Weller \& Kinchin, 2014). As observed to this point, the perceptions of the host have to be highly esteemed due to the fact that only this way it will be possible to create a culture of acceptance to peer observation; thus, shattering the idea that this academic model is invasive (Hyland et al., 2018).

Critical reflection should be done with the appropriate psychological subtlety at the time of academic deliberation. This reflection can follow specific items of the pre-observation, observation, and post-observation process. However, these items will be adjusted to the specificities of the host with emphasis on the observation stage; In other words, the perceptions of the observed teacher are the key component that will enrich the entire process of peer observation.

Some of the most outstanding components in peer observation are: the evaluative feedback on the teaching content, style, and delivery of the teaching session on aspects that could benefit from the review. On the other hand, it is necessary, the subsequent reflection and provision of concrete suggestions or general ideas for alternative approaches. Implementing changes, actively deciding not to implement changes for specific reasons or participating in an additional reflection are a direct result of the observation exercise (Dos Santos, 2017; Jones \& Gallen, 2016; Santos \& Miguel, 2016, Tenenberg, 2016). In addition, a mandatory condition for executing 
a critical reflection is that the observer has a thorough training in peerobservation matters (Kamhi-Stein, Maggioli \& De Oliveira, 2017).

\section{CONCLUSIONS}

Although observation is a valuable tool for teacher development, the widespread idea that some teachers have regarding observation as a means of intrusion into a lesson and judgment about it has led many to reject the idea of being observed. However, there are types of observations that allow teachers to learn from their colleagues and be better professionals. Peer observation is both a potentially beneficial and non-threatening strategy for teacher development that allows teachers not only to learn from peer comments but also to reflect on what we observe and see ourselves through our own practice.

Certainly, peer observation has a number of advantages; however, in the Ecuadorian context, one of the most difficult disadvantages to deal with is the monopoly of evaluation of public education policies (Hidalgo, Onofa, Oosterbeek \& Ponce, 2013). Therefore, if, in the long term, it is possible to prove that peer observation is useful, the government should take into account the efforts of the academy and not of political ideology.

When peer observation of teaching is incorporated into the practice and culture of the university and it is carried out in a mutually respectful and supportive way, it has the potential to facilitate a reflective change and teacher growth.

Therefore, it is of the utmost importance to consider peer evaluation as a policy in educational quality within the System of Evaluation of Teachers' Performance, where all the stakeholders in the process feel directly responsible for the results of students'learning.

With these considerations, the research team intends to generate an observation model to be applied at Universidad Nacional Chimborazo, which is not invasive; therefore, we believe it will have better acceptance by fellow teachers.

\section{BIBLIOGRAPHIC REFERENCES}

Alabi, J. \& Weare, W. H. Jr. (2014). Peer review of teaching: best practices for a non-programmatic approach. Communications in Information Literacy 8(2), 180-191. 
Ávila, P. (2009). La importancia de la retroalimentación en los procesos de evaluación. Una revisión del estado del arte. Universidad del Valle de México, Campus Querétaro. Disponible en: https://es.scribd.com/document/28275647/La-importancia-de-la-retroalimentacion

Brix, J., Grainger, P., \& Hill, A (2014). Investigating Mandatory Peer Review Of Teaching In Schools. Australian Journal of Teacher Education 39(4), 82-99. doi: $10.14221 /$ ajte.2014v39n4.3.

Centre for Teaching Support \& Innovation. (2017). Peer observation of teaching: Effective practices. Toronto, ON: Centre for Teaching Support \& Innovation, University of Toronto.

Contreras, G. A. (2018). Retroalimentación por Pares en la Docencia Universitaria. Una Alternativa de Evaluación Formativa. Formación universitaria 11(4), 83-94.

Díaz, M. C., Borges, A., Valadez, M. D., Zambrano, R. (2015). Valoración de buenas prácticas docentes a través de observación sistemática. Universitas Psychologica 14(3), 913-922. doi: 10.11144/Javeriana.upsy14-3.vbpd

Díaz-Maggioli, G. (2004). Teacher-centered Professional Development. [Digital book]. Virginia: Association for Supervision and Curriculum Development (ASCD). Disponible en http://www.ascd.org/publications/books/104021.aspx

Dimaté, C., Tapiero, O., González, C., Rodríguez, R. \& Arcila, M. (2017). La evaluación del desempeño docente. Folios 46, 83-95.

Donnelly, R. (2007). Perceived Impact of Peer Observation of Teaching in Higher Education. International Journal of Teaching and Learning in Higher Education 19(2), 117-129.

Dos Santos, L. M. (2017). How Do Teachers Make Sense of Peer Observation Professional Development in an Urban School. International Education Studies 10(1), 255-265. doi:10.5539/ies.v10n1p255. ISSN 1913-9020 EISSN 1913-9039.

Eri, R. (2014). Peer observation of teaching: Reflections of an early career academic. Universal Journal of Educational Research 2(9), 625-631.

Fletcher, J. A. (2018). Peer observation of teaching: a practical tool in higher education. The Journal of Faculty Development 32(1), 51-64.

González Velázquez, L. y González Velázquez, M. (2014). Evaluación de pares y coevaluación en estudiantes y docentes universitarios: Una experiencia formativa para impulsar el modelo educativo. International Journal of Developmental and Educational Psychology INFAD. Revista de Psicología 1(2), 501-508.

Grainger, G., Crimmins, K., Burton, F. (2016). Peer Review of Teaching (PRoT) in Higher Education - a Practitioner's Reflection. Reflective Practice 17(5), 523-534. doi: 10.1080/14623943.2016.1146581.

Grainger, P., Bridgstock, M., Houston, T. \& Drew, S. (2015). Working in triads: A Case Study of a Peer Review Process. Journal of University Teaching and Learning Practice 12(1), 1-27. Available at: http://ro.uow.edu.au/jutlp/ vol12/iss $1 / 3$ 
Hidalgo, D., Onofa, M., Oosterbeek, H., \& Ponce, J. (2013). Can provision of free school uniforms harm attendance? Evidence from Ecuador. Journal of Development Economics 103, 43-51. doi:10.1016/j.jdeveco.2012.12.006.

Hyland, K. M., Dhaliwal, G., Goldberg, A. N., Chen, L. M., Land, K., \& Wamsley, M. (2018). Peer Review of Teaching: Insights From a 10-Year Experience. Medical Science Educator 28(4), 675-681. doi:10.1007/s40670-0180611-9.

Jones, M. H., \& Gallen, A. M. (2016). Peer observation, feedback and reflection for development of practice in synchronous online teaching. Innovations in Education and Teaching International 53(6), 616-626. doi:10.1080/1470329 7.2015.1025808.

Kamhi-Stein, L. D., Maggioli, G. D., \& De Oliveira, L. C. (eds.). (2017). English language teaching in South America: Policy, preparation and practices. U.K: Multilingual Matters.

Keig, L. (2000). Formative peer review of teaching: Attitudes of faculty at liberal arts colleges toward colleague assessment. Journal of Personnel Evaluation in Education 14(1), 67-87. doi:10.1023/a:1008194230542.

Kohut, G., Burnap C. \& Yon, M. (2007). Peer Observation of Teaching: Perceptions of the Observer and the Observed. College Teaching 55(1), 19-25.

Magaña Figueroa, C. A., \& Flores Hernández, E. (2015). La observación entre pares: aprendiendo de un reflejo / Peer observation: learning of a reflection. RIDE Revista Iberoamericana para la Investigación y el Desarrollo Educativo 6(11), 553. doi:10.23913/ride.v6i11.158.

Martin, G. \& Double, J. (1998) Developing Higher Education Teaching Skills Through Peer Observation and Collaborative Reflection. Innovations in Education \& Training International 35(2), 161-170. doi: $10.1080 / 1355800980350210$

Martínez Iñiguez, J. E., Tobón, S., \& Romero Sandoval, A. (2017). Problemáticas relacionadas con la acreditación de la calidad de la educación superior en América Latina. Innovación educativa 17(73), 79-96.

Mohammed, J. (2017). The Effect of Peer Assessment on the Evaluation Process of Students. Canadian Center of Science and Education. International Education Studies 10(6). ISSN 1913-9020 E-ISSN 1913-9039.

Motallebzadeh, K., Hosseinnia, M., \& Domskey, J. G. (2017). Peer observation: A key factor to improve Iranian EFL teachers professional development. Cogent Education 4(1), 1-12. doi:10.1080/2331186x.2016.1277456.

Muñoz, A., Villagra, J., Sepúlveda, E. (2016). Proceso de reflexión docente para mejorar las prácticas de evaluación de aprendizaje en el contexto de la educación para jóvenes y adultos (EPJA). Folios 44, 77-91. Recuperado de http://www.scielo.org.co/scielo.php?script=sci_arttext\&pid=S0123-4870 2016000200005\&lng=en\&tlng=es.

O'Leary, M. \& Price, D. (2016). Peer observation as a springboard for teacher learning. En M. O’Leary (ed.) Reclaiming lesson observation: supporting excellence in teacher learning (pp. 114-123). New York, USA: Routledge. 
Consejo de Educación Superior (2012). Reglamento de Carrera y Escalafón del profesor e investigador del sistema de educación superior. Disponible en https://www.ces.gob.ec/doc/historico_LOTAIP/LOTAIP2015/Anexos/reglamento $\% 20$ de $\% 20$ carrera $\% 20 y \% 20$ escalafon $\% 20$ del $\% 20$ profesor $\% 20 \mathrm{e} \% 20$ investigador\%20del\%20sistema\%20de\%20educacion\%20superior.pdf

Reyes-Chua, E., Remollo-Mack, M., \& Viloria, A. O. (2019). Teachers' perceptions on the classroom peer observation exercise at eac-cavite, Philippines. European Journal of Human Resource Management Studies 2(2), 97-110.

Richard, C. L., Lillie, E., Mathias, K., \& McFarlane, T. (2019). Impact and Attitudes about Peer Review of Teaching in a Canadian Pharmacy School. American journal of pharmaceutical education 83(6), 90-99. doi: 10.5688/ ajpe6828.

Ronquillo, S., Moreira, A., \& Verdesoto, O. (2016). La evaluación docente una propuesta para el cambio en la Facultad de Administración de la universidad ecuatoriana. Revista Universidad y Sociedad [seriada en línea] 8(2), 125-131. Disponible en: de http://rus.ucf.edu.cu/

Santos, L. M. D., \& Miguel, L. (2016). Foreign language teachers' professional development through peer observation programme. English Language Teaching 9(10), 39-46. doi:10.5539/elt.v9n10p39.

Tenenberg, J. (2016). Learning through observing peers in practice. Studies in Higher Education 41(4), 756-773. doi:10.1080/03075079.2014.950954.

Toscanini Segale, M., Aguilar Guzmán, A., y García Sánchez, R. (2016). Diagnóstico de las políticas públicas de la educación superior en el Ecuador. Revista Cubana de Educación Superior 35(3), 161-178.

UNESCO (2014). Temas críticos para formular nuevas políticas docentes en América Latina y el Caribe. El debate actual. París: Centro de Estudios de Políticas y Prácticas en Educación (CEPPE).

Valero, B., \& Blasco, J.S. (2013). Evaluación de pares y autoevaluación en el aula universitaria: una visión con enfoque por competencias. Universidad Católica de Valencia San Vicente Mártir. Disponible en: web.ua.es/en/ice/ Jornadas-redes/documentos/ 2013-posters/33209.pdf

Vizcaíno, C., Marín, F., \& Ruiz, E. (2017). La coevaluación y el desarrollo del pensamiento crítico. Advocatus 28, 141-149. doi: 10.18041/0124-0102/advocatus.28.892.

Wajnryb, R. (1992). Classroom observation tasks: A resource book for language teachers and trainers. Cambridge, UK: Cambridge University Press.

Wingrove, D., Hammersley-Fletcher, L., Clarke, A., \& Chester, A. (2017). Leading Developmental Peer Observation of Teaching in Higher Education: Perspectives from Australia and England. British Journal of Educational Studies 66(3), 365-381.

Yiend, J., Weller, S., \& Kinchin, I. (2014). Peer observation of teaching: The interaction between peer review and developmental models of practice. Journal of Further and Higher Education 38(4), 465-484. doi:10.1080/0309 877x.2012.726967. 